Editorial

\title{
Are All Joints Equal? Synovial Fluid Analysis in Periprosthetic Joint Infection
}

\author{
Parham Sendi, ${ }^{1,2,3 凶}$ Andreas M. Müller, ${ }^{2}$ Elie Berbari ${ }^{4}$ \\ 1. Department of Infectious Diseases and Hospital Epidemiology, University Hospital Basel, University Basel, Basel, Switzerland \\ 2. Department of Orthopaedics and Traumatology, University Hospital Basel, Basel, Switzerland. \\ 3. Institute for Infectious Diseases, University of Bern, Bern, Switzerland \\ 4. Division of Infectious Disease, Mayo Clinic College of Medicine, Rochester, Minnesota, USA. \\ $\triangle$ Corresponding author: Parham Sendi, MD, Institute for Infectious Diseases, University of Bern, Friedbühlstrasse, 51, CH-3001, Bern, Switzerland. Telephone \\ +4131632 69 86; Fax +4131632 86 77. Parham.Sendi@ifik.unibe.ch \\ (C) Ivyspring International Publisher. This is an open access article distributed under the terms of the Creative Commons Attribution (CC BY-NC) license \\ (https://creativecommons.org/licenses/by-nc/4.0/). See http://ivyspring.com/terms for full terms and conditions.
}

Published: 2018.12.04

Neutrophils play a key role when recruited into circulation and to sites of infection or inflammation. Synovial fluid Gram-staining and microbiological studies have been implemented for the diagnostic work-up of both native and prosthetic joint infections (PJIs) for many decades. Joint synovial fluid cell count and differential analysis has been traditionally used to elucidate the underlying cause of acute native arthritis. Leukocyte count and differential were introduced in the diagnostic workup of PJI between 1998 and 2004. Over the past 20 years, several studies assessed the diagnostic accuracy of leukocyte count and differential from synovial fluid in patients with suspected PJI [1-10]. These studies identified the optimal cut-off value for PJI diagnosis to be approximately more than one log lower than for native joint septic arthritis. In earlier studies, these lower values produced unit errors in the transition from native to prosthetic joints infection [11]. Leukocytes $/ \mu \mathrm{L}$ or leukocytes/ $10^{-3} \mathrm{~cm}^{3}$ are the currently recommend units for synovial cell count analyses. In parallel to these studies, laboratory institutions switched from manual to automated cell counting [12,13], and cell count cut-off values were extrapolated to arthroplasties other than hip and knee joints [14]. For simplicity, providers tend to use one single optimal cut-off value irrespective of anatomic location of the prosthetic joint.

Many preanalytical steps are required from joint aspiration to cell counting (see Table 1). Variability of these steps may influence the result. Various institutions use different machines for cell counting. Thus, it is conceivable that there are inter-institutional variations of the optimal cut-off cell count value for the diagnosis of PJI (Table 2). To the best of our knowledge, there are no published data assessing inter-machine or inter-institutional synovial fluid cell count comparisons in the diagnosis of PJI. In addition, many of studies on the optimal cut-off cell count for the diagnosis of PJI have included a mix of patients with acute, chronic, early or late infections. Therefore, from a clinical point of view, PJI should be suspected when falling above a range of cell count instead of a precise cut-off value (Table 2). In addition, synovial cell count result is only one of several diagnostic pieces that may lead to a definite diagnosis of PJI.

Cut-off values ranging from 2500 to 5000 leukocytes $/ \mu \mathrm{L}$ and $60 \%$ to $89 \%$ for polymorphonuclear leukocytes (PMN) for the diagnosis of hip and knee PJI have been published [15]. The comparison of these studies is difficult because of the aforementioned variability of cell count results and lack of gold standard definition of PJI diagnosis. However, it seems that cut-off values for infection in total knee arthroplasty are lower than those in total hip arthroplasty (Table 2). The reason for this tendency is unclear but may be related to the anatomy, the size of the joint, synovial fluid volume and its vascularization. These arguments are in line with the observation that synovial fluid analysis is rarely possible in suspected ankle PJI [16].

In this issue of JBJI, Strahm and colleagues 
investigated the optimal cut-off values in patients with shoulder PJI [17]. Their findings are compelling and surprising. Firstly, nearly a third of these cases (11 of 39 punctures) resulted in a dry tap. Secondly, the optimal cut-off value for PMN was in the rage of known values for the diagnosis of PJI $(>54 \%)$. However, the cutoff for leukocyte count was $12,200 / \mu \mathrm{L}$ (sensitivity $100 \%$ and specificity $75 \%$ ). Thirdly, infection due to low virulent organisms (e.g.; Cutibacterium spp.) were associated with a high synovial cell counts. The authors points towards the limitations of their study, including the small sample size and its retrospective nature. Consequently, the interpretation of these results require confirmation in a larger setting. Nonetheless, the work of Strahm et al. [17] may indicate that cutoffs value of cell count may be affected by joint site.

Table 1. Factors potentially influencing the results of cell count and differential result in synovial fluid.

Drugs in the joint (e.g.; local anaesthetics)

Insufficient puncture volume ( $\geq 1 \mathrm{~mL}$ preferred)

Insufficient mixture of synovial fluid with EDTA in the tube (inversion of the EDTA tube multiple times immediately after filling)

Viscosity (treatment with hyaluronidase required)

Pus, fibrinogen resulting in clots (counting in a conventional haemocytometer chamber).

Clots during transport to the laboratory or while awaiting testing

Lysis of cells during transport to the laboratory or while awaiting testing.

The list in this table is not exhaustive.

Table 2. Selected publications revealing cut-off values for synovial cell count and differential in patients with periprosthetic hip and knee joint infections.

\begin{tabular}{|c|c|c|c|c|}
\hline References & $\begin{array}{l}\text { Sample } \\
\text { number }\end{array}$ & Joint & Cut-off Leukocytes & Cut-off \% PMN \\
\hline [4] & 133 patients & Knee & $>1700$ cells $/ \mu \mathrm{L}$ & $>65 \%$ \\
\hline [10] & 429 joints & Knee & $>1100$ cells $/ \mu \mathrm{L}$ & $>64 \%$ \\
\hline [7] & $\begin{array}{l}150 \text { cases in } \\
145 \text { joints and } \\
144 \text { patients }\end{array}$ & Knee & $\geq 3000$ cells $/ \mu \mathrm{L}$ & $>75 \%$ \\
\hline [6] & $\begin{array}{l}803 \text { patients }^{+} \\
871 \text { joints }\end{array}$ & $\begin{array}{l}\text { Knee } \\
+ \text { Hip }\end{array}$ & $\begin{array}{l}>3450 \text { cells } / \mu \mathrm{L}^{\mathrm{a}} \\
>3444 \text { cells } / \mu \mathrm{L}^{\mathrm{b}}\end{array}$ & $\begin{array}{l}>78 \% \mathrm{a} \\
>75 \% \mathrm{~b}\end{array}$ \\
\hline [9] & 75 patients & $\begin{array}{l}\text { Knee } \\
+ \text { Hip }\end{array}$ & $>1590$ cells $/ \mu 1$ & $>65 \%$ \\
\hline [1] & $\begin{array}{l}202 \text { joints } \\
178 \text { patients }\end{array}$ & Hip & $\begin{array}{l}\left(>50.0 \times 10^{9} \text { cells } / \mathrm{L}\right) \\
>50000 \text { cells } / \mu \mathrm{L}^{\&}\end{array}$ & $>80 \%$ \\
\hline [5] & $\begin{array}{l}235 \text { joints } \\
220 \text { patients }\end{array}$ & Hip & $\begin{array}{l}>4200 \text { cells } / \mu \mathrm{L} \\
>3000 \text { cells } / \mu \mathrm{L}^{*}\end{array}$ & $>80 \%$ \\
\hline [8] & 453 patients $¥$ & Hip & 3966 cells $/ \mu \mathrm{L}$ & $>80 \%$ \\
\hline
\end{tabular}

Footnotes:

*When synovial cell count results was combined with an elevated erythrocyte sedimentation rate and C-reactive protein level, the optimal cut-off value was $>3000$ cells $/ \mu \mathrm{L}$.

+Study including 810 patients with noninflammatorya and 61 patients with

inflammatory arthritis

‡ The study focusses on chronic PJI.

\& Cut-off defined prior to the study without ROC curve.

\section{Competing Interests}

The authors have declared that no competing interest exists.

\section{References}

1. Spangehl MJ, Masri BA, O'Connell JX, Duncan CP. Prospective analysis of preoperative and intraoperative investigations for the diagnosis of infection at the sites of two hundred and two revision total hip arthroplasties. The Journal of bone and joint surgery American volume. 1999; 81: 672-83.

2. Kersey R, Benjamin J, Marson B. White blood cell counts and differential in synovial fluid of aseptically failed total knee arthroplasty. J Arthroplasty. 2000; 15: 301-4.

3. Mason JB, Fehring TK, Odum SM, Griffin WL, Nussman DS. The value of white blood cell counts before revision total knee arthroplasty. J Arthroplasty. 2003; 18: 1038-43.

4. Trampuz A, Hanssen AD, Osmon DR, Mandrekar J, Steckelberg JM, Patel R. Synovial fluid leukocyte count and differential for the diagnosis of prosthetic knee infection. The American journal of medicine. 2004; 117: 556-62.

5. Schinsky MF, Della Valle CI, Sporer SM, Paprosky WG. Perioperative testing for joint infection in patients undergoing revision total hip arthroplasty. The Journal of bone and joint surgery American volume. 2008; 90: 1869-75.

6. Cipriano CA, Brown NM, Michael AM, Moric M, Sporer SM, Della Valle CJ. Serum and synovial fluid analysis for diagnosing chronic periprosthetic infection in patients with inflammatory arthritis. The Journal of bone and joint surgery American volume. 2012; 94: 594-600.

7. Zmistowski B, Restrepo C, Huang R, Hozack WJ, Parvizi J. Periprosthetic joint infection diagnosis: a complete understanding of white blood cell count and differential. J Arthroplasty. 2012; 27: 1589-93.

8. Higuera CA, Zmistowski B, Malcom T, Barsoum WK, Sporer SM, Mommsen $\mathrm{P}$, et al. Synovial Fluid Cell Count for Diagnosis of Chronic Periprosthetic Hip Infection. The Journal of bone and joint surgery American volume. 2017; 99: 753-9.

9. Dinneen A, Guyot A, Clements J, Bradley N. Synovial fluid white cell and differential count in the diagnosis or exclusion of prosthetic joint infection. Bone Joint J. 2013; 95B: 554-7.

10. Ghanem E, Parvizi J, Burnett RS, Sharkey PF, Keshavarzi N, Aggarwal A, et al. Cell count and differential of aspirated fluid in the diagnosis of infection at the site of total knee arthroplasty. The Journal of bone and joint surgery American volume. 2008; 90: 1637-43.

11. Elsissy PG, Stevens WT, Ellsworth B, Karkare N. Cell count and differential of aspirated fluid in the diagnosis of infection at the site of total knee arthroplasty. The Journal of bone and joint surgery American volume. 2010; 92: 1312; author reply -4

12. Salinas M, Rosas J, Iborra J, Manero H, Pascual E. Comparison of manual and automated cell counts in EDTA preserved synovial fluids. Storage has little influence on the results. Ann Rheum Dis. 1997; 56: 622-6.

13. de Jonge R, Brouwer R, Smit M, de Frankrijker-Merkestijn M, Dolhain RJ, Hazes JM, et al. Automated counting of white blood cells in synovial fluid. Rheumatology (Oxford). 2004; 43: 170-3.

14. Piper KE, Jacobson MJ, Cofield RH, Sperling JW, Sanchez-Sotelo J, Osmon DR, et al. Microbiologic diagnosis of prosthetic shoulder infection by use of implant sonication. J Clin Microbiol. 2009; 47: 1878-84.

15. Qu X, Zhai Z, Liu X, Li H, Wu C, Li Y, et al. Evaluation of white cell count and differential in synovial fluid for diagnosing infections after total hip or knee arthroplasty. PLoS One. 2014; 9: e84751.

16. Sendi P, Kessler B, Knupp M. Periprosthetic Joint Infection after Ankle Arthroplasty. In: Zimmerli W, editor, one and Joint Infections: From Microbiology to Diagnostics and Treatment: Wiley-Blackwell; 2015.

17. Strahm C, Zdravkovic V, Egidy C, Jost B. Count in Patients with Shoulder Prosthetic Joint Infection. J. Bone Jt. Infect. 2018; 3(5): 245-248. 